\title{
REGULATING THE CRIMINAL PROCEDURAL STATUS OF OLDER PERSONS AS AN ELEMENT OF CRIMINAL POLICY: NATIONAL AND INTERNATIONAL ASPECTS
}

\author{
Lev V. Bertovskiy ${ }^{1}$ \\ Svetlana M. Kurbatova ${ }^{2}$
}

\begin{abstract}
The relevance of the present study lies in the importance of observing human rights in all spheres, and especially in the field of criminal proceedings, taking into account its specifics and possible consequences for the persons involved. This is especially true for persons who, due to their cognitive capabilities, cannot always fully exercise their rights, and therefore cannot be full participants in criminal proceedings. Worldwide, the number of older persons is increasing, as does the likelihood of their involvement in criminal proceedings. At the international and national levels, the peculiarities of the legal status of minors are reflected in the legislation, yet no such rules of a compensatory nature exist for persons of old age. The current situation leads to the violation of their rights and necessitates the improvement of criminal policy both at the national
\end{abstract}

and international levels, as well as the need for relevant scientific research. In this regard, the present research aims to identify or disclose the age characteristics of older persons in the context of the influence on the ability of these subjects to be full-fledged participants in criminal proceedings; to raise the issue of the need to reflect (in the content of criminal policy) the importance of legislative consolidation of the special legal status of these participants both at the national and international levels, including providing them with additional procedural guarantees (by analogy with the peculiarities of the participation of minors in criminal proceedings). Working on the issue, a cognitive approach was used, as well as general scientific and special, theoretical and empirical methods, which allowed comprehensively considering a number

\footnotetext{
${ }^{1}$ People’s Friendship University of Russia, Moscow, Russia. E-mail: bgl1980@ yandex.ru

${ }^{2}$ Krasnoyarsk State Agrarian University; Siberian Federal University, Krasnoyarsk, Russia; E-mail: $\underline{\text { sveta_kurbatova@mail.ru }}$
} 


\section{।}

GÊNERO E

INTERDISCIPLINARIDADE

of aspects related to the research topic.

The study presents the analysis of scientific literature and empirical research on the topic; a number of problems of national and international importance are identified concerning the legal situation (in the criminal process) of older persons; a number of proposals for improving the directions of the criminal policy of individual states and of the international community as a whole regarding the legislative consolidation of the peculiarities of the legal status of older participants is substantiated. The materials of the present research are of practical value for law enforcement agencies, for legislative, executive and judicial authorities, human rights organizations, and educational institutions.

Keywords: legal status, participants in criminal proceedings, older groups, cognitive functions, legal guarantees.

\section{Introduction}

Numerous international legal documents reflect the ideas of equality, revealed through the prohibition of discrimination, requirements to respect fundamental human rights and freedoms, etc. However, due to certain reasons (health status, hostilities, change in
Vol $^{\circ} 02$ | nº 01 | ISSN: 2675-7451

https://www.periodicojs.com.br/index.php/gei/index

social status, etc.), entire categories of the population may 'drop out' from the general mass, requiring, as a result, various types of additional support from society and the state, and if this process is global, from the international community as a whole.

The global tendency of the ageing of the population is among such processes and requires the need to address its consequences not only at the national but also at the international levels.

Thus, in Russia, according to the official state statistics service (Federal State Statistics Service) people over 65 years old already account for almost a quarter of the population, and Credit Suisse predicts that by 2060 , their share will grow to $47 \%$ (Credit Suisse, Russian); is also confirmed by the research of the World Bank (Age dependency ratio...)

An increase in the number of older people is also noted worldwide: If back in 1950, people over 65 accounted for $7.7 \%$ of the world's population, in 2019 the share increased to $19 \%$, and in 2050 it will exceed $27 \%$, despite the fact that the life expectancy of people around the world is growing - from 47 years in 1950 to 72 years in 2019. Biological age has ceased to coincide with the 


\section{1}

GÊNERO E

INTERDISCIPLINARIDADE

chronological age - today a resident of

Switzerland at 65 feels the same way as

a 51-year-old Swiss in 1950s. By 2050,

life expectancy will grow even more - to about 77 years (Credit Suisse, English).

Understanding of this was reflected in age periodization. Since 1962, in numerous countries the periodization of the First World Symposium of Gerontologists has been used: $40-60$ is middle age, $60-75$ is the elderly, 75-90 - senile, and over 90 long livers. In 2009, the World Health Organization, taking into account the changed reality associated with the increase in the life of the population, proposed a new periodization, excluding the old age from the previous one. The period from 60 to 75 years became late maturity, 75 to 90 is old age, afterwards come long livers (Blekharskaya, 2017).

However, the following should be considered. With age, the cognitive functions of the brain decrease; this complicates the processes of proper perception of the surrounding reality and limits the ability to carry out actions and control them. This entails formulating the general question about the possibility of participants in legal relations to properly independently exercise their rights and obligations. After all, the fact of living in society and the presence of a
$\mathrm{Vol}^{\circ} 02$ | nº 01 | ISSN: 2675-7451

https://www.periodicojs.com.br/index.php/gei/index

two-way legal relationship with the state in the form of citizenship impose the inevitability of being involved in the most diverse types of legal relations, sometimes not at will, for example, in criminal procedural legal relations.

A vital issue due to an increase in life expectancy and in the share of older people in the total mass of the world population is the lack of appropriate international legal frameworks for securing the legal status of this category of the population as of participants in various spheres of social relationships. Currently existing international normative acts mainly regulate issues of a social nature. As a result, entire sectors of public relations where such persons are involved are not covered by legal regulation, which, in the context of human rights, acquires special significance, thereby contributing to a discriminatory approach towards older persons.

This is especially true for the areas covered by the criminal policy of states, taking into account their specificity (the stressful nature for participants, possible negative consequences, etc.) (Agnew, DeLisi, 2012; Morris, et al., 2012).

However, criminal policy is a complex multi-component concept, 


\section{।}

GÊNERO E

INTERDISCIPLINARIDADE

including areas such as criminal law, criminal justice and penal law (Galperin, Kurlyandsky, 1975), among others (Malysheva, 2005). The first three are basic and closely related, so it is natural that the changes occurring in one of them affect the rest. Thus, based on the global trend towards the humanization of criminal policy, corresponding to the general spirit of the modern era of human development, this should initially be reflected in the norms of criminal law, then in criminal procedure and then in criminal executive law.

Nevertheless, each of these spheres of public relations has its own specifics; therefore, when considering individual issues and conducting relevant scientific research, the peculiarities of a particular branch of law should be taken into account in order to obtain the maximum result. For instance, with regard to the older categories, the age peculiarities of their legal status are reflected in the norms of criminal and penal law, but in most countries the issues of their participation in criminal proceedings remain unresolved. This is precisely the situation in the Russian Federation.

These persons may participate in criminal proceedings as suspects, accused (defendants), victims,
$\operatorname{Vol}^{\circ} 02$ | nº 01 | ISSN: 2675-7451

https://www.periodicojs.com.br/index.php/gei/index

witnesses, attesting witnesses, jurors, etc., and given the trend towards an everincreasing number of the older population, the likelihood of their obtaining a certain procedural status also increases. Accordingly, it is necessary to take into account those features of the functioning of the body which are predetermined by age. It should be borne in mind that the specifics of the nature of criminal procedural relations and the psychological stress experienced by many full-fledged participants (Musiychuk, Shuleva, 2018), have a much stronger effect on older persons due to the peculiarities of their state of mind and psychology (Aguzumtsyan, Muradyan, 2008).

Numerous psychological, gerontological, social and other studies show that:

- in older people, memory changes occur, physical indicators worsen, and health problems arise: the quality of most simple sensory functions (vision, hearing, taste, touch and more complex ones (psychomotorics, perception of new things, memorization, all human behavior, including the ability to adapt to changing conditions, and to abstract logical thinking) worsen (Melekhin, Sergienko, 2015); 


\section{1}

GÊNERO E

INTERDISCIPLINARIDADE

- by the age of 50-60, due to ageing of the brain, mental performance decreases by $20-40 \%$; if before 50 , the decline in mental functions is smooth and imperceptible, after 50 and especially after 55 , signs of weakening of memory, attention, thinking are already more pronounced (Yakimovich, n.d.), and changes occur in the model of mental perception (Wang, Su, 2013);

- as a person gets older, their brain shrinks; by the age of 80 , the hippocampus, which plays a decisive role in memory processes, loses $20-30 \%$ of its neurons, and slow extinction begins (Larry, 1987), yet this process can begin earlier and be accelerated due to diseases (Raz, 2000) and to negative environmental influences, including those of stressful nature (Zerbi, Valerio, Floriou-Servou, Amalia et al., n.d.);

- spatial abilities (skills responsible for the mental manipulation of space and the arrangement of objects) remain unchanged until about 60 years old, after which a decrease in productivity is observed. The logical thinking test is best performed by people between the ages of 35 and 45, and then a decrease in the average indicators also begins. Comprehension of words improves up to 55-60 years old, a decrease occurs by 65-70 years. The
$\mathrm{Vol}^{\circ} 02$ | nº 01 | ISSN: $2675-7451$

https://www.periodicojs.com.br/index.php/gei/index

arithmetic test is almost equally successfully performed by subjects from 25 to 60 years old (with some progressive improvement), deterioration occurs after 60 years (Goryunova, Voronin, 2016), exerting an increasing influence on the mind with age (Cavallini, Lecce, 2013).

All this is even more pronounced when the subject has cerebrovascular (Rwei-Ling, Ruey-Meei, 2013) and neurodegenerative disorders (Choong, Doody, 2013).

Thus, the hypothesis of the present research was as follows: it is necessary to legislatively consolidate the special procedural status of older participants in criminal proceedings which would be aimed at:

1. realization of human rights in criminal proceedings;

2. compliance with global trends in the humanization of criminal procedure (as part of criminal) policy;

3. observance of the legitimate interests of a particular person in the field of criminal proceedings (Grinenko, Gudzhabidze, Potapov, Zheleznyak, 2020)

4. assistance in harmonizing the formation and implementation of the criminal procedure (as part of the criminal) policy of an individual state 


\section{।}

GEENERO E

INTERDISCIPLINARIDADE

(Kesaeva, 2017) and groups of states (Sorokina, 2016);

5. development of the foundations of a global criminal policy in relation to older persons: recognition of them as participants with a special legal status and endowing the with additional guarantees.

\section{Materials and methods}

The research methodology was predetermined by the topic and aim:

- the research aimed to study the older age characteristics in the context of their influence on the person's ability to be full-fledged participant in criminal proceedings; to raise the issue of reflecting in the content of criminal policy the importance of legislative consolidation of the special legal status of these participants both at the national and international levels, including providing them with additional procedural guarantees (by analogy with the peculiarities of the participation of minors in criminal proceedings);

- research methods: general scientific (logical, statistical and comparative analysis, synthesis,
$\mathrm{Vol}^{\circ} 02$ | nº 01 | ISSN: 2675-7451

https://www.periodicojs.com.br/index.php/gei/index

induction, deduction, analogy, etc.) and special (empirical, sociological, comparative legal, modeling);

- research participants: older persons* who either participated or not in criminal proceedings as accused, victims, witnesses, and also judges; advocates, lawyers and representatives of human rights organizations.

- research materials: scientific works in the field of jurisprudence, psychology, gerontology and other sciences, touching upon the issues raised in the present study; materials of criminal cases; statistical data and data obtained from interviewing respondents.

* under the category of 'older persons' the authors of the present research mean persons from 60 years of age and older, based on the periodization proposed in 2009 by the World Health Organization.

\section{Results}

The research conducted by the authors after studying the materials of 52 criminal cases involving persons from 60 to 87 years showed the following results (Table 1): 
Table 1. Influence of age on the cognitive functions of participants in criminal proceedings*

\begin{tabular}{|c|c|c|c|c|}
\hline $\begin{array}{c}\text { age } \\
\text { category of } \\
\text { participants } \\
\text { (years) }\end{array}$ & $\begin{array}{l}\text { perceiving } \\
\text { information } \\
\text { (percentage of } \\
\text { age group and } \\
\text { score on the } \\
\text { scale of } \\
\text { effectiveness) }\end{array}$ & $\begin{array}{l}\text { processing } \\
\text { information } \\
\text { (percentage of } \\
\text { age group and } \\
\text { score on the } \\
\text { scale of } \\
\text { effectiveness) }\end{array}$ & $\begin{array}{c}\text { storing } \\
\text { information } \\
\text { (percentage of } \\
\text { age group and } \\
\text { score on the } \\
\text { scale of } \\
\text { effectiveness) }\end{array}$ & $\begin{array}{l}\text { transmitting } \\
\text { information } \\
\text { (percentage of } \\
\text { age group and } \\
\text { score on the } \\
\text { scale of } \\
\text { effectiveness) }\end{array}$ \\
\hline $60-65$ & $\begin{array}{c}81 \%-3 \\
17 \%-2 \\
2 \%-1 \\
-\end{array}$ & $\begin{array}{c}75 \%-3 \\
19 \%-2 \\
5 \%-1 \\
1 \%-0\end{array}$ & $\begin{array}{c}79 \%-3 \\
16 \%-2 \\
5 \%-1 \\
-\end{array}$ & $\begin{array}{c}80 \%-3 \\
18 \%-2 \\
2 \%-1 \\
-\end{array}$ \\
\hline $65-70$ & $\begin{array}{c}52 \%-3 \\
39 \%-2 \\
8 \%-1 \\
1 \%-0\end{array}$ & $\begin{array}{c}59 \%-3 \\
30 \%-2 \\
10 \%-1 \\
1 \%-0\end{array}$ & $\begin{array}{c}57 \%-3 \\
32 \%-2 \\
11 \%-1 \\
-\end{array}$ & $\begin{array}{c}60 \%-3 \\
26 \%-2 \\
13 \%-1 \\
1 \%-0\end{array}$ \\
\hline $70-75$ & $\begin{array}{c}25 \%-3 \\
40 \%-2 \\
33 \%-1 \\
2 \%-0\end{array}$ & $\begin{array}{c}20 \%-3 \\
41 \%-2 \\
35 \%-1 \\
4 \%-0\end{array}$ & $\begin{array}{c}18 \%-3 \\
38 \%-2 \\
38 \%-1 \\
4 \%-0\end{array}$ & $\begin{array}{c}16 \%-3 \\
37 \%-2 \\
43 \%-1 \\
4 \%-0\end{array}$ \\
\hline $75-80$ & $\begin{array}{l}15 \%-3 \\
28 \%-2 \\
46 \%-1 \\
11 \%-0\end{array}$ & $\begin{array}{l}11 \%-3 \\
28 \%-2 \\
49 \%-1 \\
12 \%-0\end{array}$ & $\begin{array}{c}9 \%-3 \\
21 \%-2 \\
55 \%-1 \\
15 \%-0\end{array}$ & $\begin{array}{c}8 \%-3 \\
22 \%-2 \\
59 \%-1 \\
11 \%-0\end{array}$ \\
\hline over 80 & $\begin{array}{c}1 \%-3 \\
11 \%-2 \\
55 \%-1 \\
33 \%-0\end{array}$ & $\begin{array}{c}- \\
10 \%-2 \\
51 \%-1 \\
39 \%-0\end{array}$ & $\begin{array}{c}4 \%-3 \\
14 \%-2 \\
38 \%-1 \\
44 \%-0\end{array}$ & $\begin{array}{c}- \\
8 \%-2 \\
57 \%-1 \\
35 \%-0\end{array}$ \\
\hline
\end{tabular}

* the following efficiency scale was used:

3 (points)-excellent;

2 (points) - good;

1 (point) - satisfactory;

$O$ (points) - unsatisfactory.

Respectively:

- the participants aged 60-70 had minor problems with the perception, processing, storage and transmission of information, yet in general these were insignificant in terms of exercising rights; 


\section{।}

E Gênero e

INTERDISCIPLINARIDADE

- in the participants aged 70-75,

these problems became more pronounced;

- the participants aged 75-80 had

obvious difficulties with certain processes;
$\mathrm{Vol}^{\circ} 02\left|\mathrm{n}^{\circ} 01\right|$ ISSN: 2675-7451

https://www.periodicojs.com.br/index.php/gei/index

- for the participants over 80 years old, all the processes were difficult. Within the framework of the study, 46 judges of the Russian Federation were asked the following questions (Table 2):

Table 2. Questionnaire results

\begin{tabular}{|c|c|c|}
\hline Question & $\begin{array}{l}\text { Yes } \\
(\% \\
\text { ppl })^{(\%}\end{array}$ & $\begin{array}{l}\text { No } \\
(\% \\
\text { ppl })\end{array}$ \\
\hline $\begin{array}{l}\text { Do you agree that the amount of a person's cognitive } \\
\text { abilities affects their ability to exercise their rights and } \\
\text { obligations as a participant in criminal proceedings? }\end{array}$ & 98 & 2 \\
\hline $\begin{array}{l}\text { Do you think that the reflection of modern ideas } \\
\text { about the essence of the welfare state in the Criminal } \\
\text { Procedure Code of the RF in relation to older participants } \\
\text { in criminal proceedings is sufficient? }\end{array}$ & 0 & 100 \\
\hline $\begin{array}{l}\text { Do you think it would be natural if the Criminal } \\
\text { Procedure Code of the RF reflected the peculiarities of the } \\
\text { legal status of the older accused by analogy with minors, } \\
\text { since with age, a person's cognitive abilities decrease and, } \\
\text { therefore, a person cannot fully exercise their rights? }\end{array}$ & 100 & 0 \\
\hline
\end{tabular}

When asked about the age at which it is necessary to provide additional guarantees to older participants in criminal proceedings, the opinions were as follows:

- from 65 years old - 6\%;

- from 70 years old $-28 \%$;
- from 75 years old - 62\%;

- from 80 and older $-4 \%$.

When asked what additional compensatory guarantees should be provided in criminal proceedings to older persons who have difficulties with the proper implementation of their legal 


\section{।}

GÊNERO E

INTERDISCIPLINARIDADE

status, the following answers were received:

- the obligatory participation of a lawyer-representative (including at the expense of the state);

- mandatory participation of a legal representative;

- the obligatory participation of a psychologist (if possible, a psychologistgerontologist).

In the course of the study, 24 lawyers and representatives of public human rights organizations were interviewed. They all spoke positively about the following postulates:

- older persons need special care from the state not only in the field of health and social protection but also in others, including in criminal proceedings;

- it is necessary to change the Russian criminal procedural legislation regarding the consolidation of the special legal status of participants from among older persons;

- the content of the national criminal policy should be revised taking these features into account;

- a necessary measure to ensure all of the above at the national level is the formation of an international legal framework (by analogy with international norms governing the
Vol $^{\circ} 02$ | nº 01 | ISSN: 2675-7451

https://www.periodicojs.com.br/index.php/gei/index

peculiarities of the legal status of juvenile participants in criminal proceedings).

\section{Discussion}

The results of the study revealed that about $80 \%$ of the older participants could not properly and fully understand the situation and perceive and transmit information - that is could not fully exercise their rights and fulfill their duties as participants in criminal proceedings.

Therefore, a problem arises: in the criminal process, older persons cannot fully realize themselves as its participants. This entails a violation of their human rights to universal equality, creates conditions for their discrimination against other participants, and complicates the functioning of the welfare state model in specific countries as a means of ensuring the legal status of persons with cognitive disabilities (Kurbatova, 2019b).

The solution here is the adoption of compensatory legal norms which would take into account the peculiarities of the age development of these categories of the population, and, through additional rights and guarantees for implementation (including imposition of certain duties on the 


\section{1}

GÊNERO E

INTERDISCIPLINARIDADE

authorities and officials conducting the proceedings) would equalize the legal status of these participants. Wherein:

- for persons over 75 years of age, such guarantees would be mandatory in criminal proceedings;

- for persons aged 65-75, these would be applied at the initiative of the authority conducting the criminal proceedings or at the request of other participants (for example, a defense attorney) if there were doubts about the possibility of such persons to exercise their rights independently.

These and other issues need to be reflected in the formation of national criminal policy; therefore, it would be very important to have a certain international legal framework that would consolidate the foundations of the legal status of older persons in criminal proceedings, and determine the guarantees of its implementation, which would determine a benchmark for the further development of the criminal policy of national states in solving this issue.

In general, there is a positive trend - at the international level one can already observe certain results of recognizing the special status of the olderly:
$\mathrm{Vol}^{\circ} 02$ | nº 01 | ISSN: $2675-7451$

https://www.periodicojs.com.br/index.php/gei/index

- a base of international legal acts was created that regulate certain aspects concerning the life of older persons: 1982 Vienna International Plan of Action on Ageing (of a recommendatory nature; was the first recognition of the problem and of the need for collective work towards its solution), 1991 UN Principles for Older Persons (a set of ethical norms and rules that reflect the attitude of the world community towards a specific group of people - the olderly), 1992 Declaration on Ageing (outlined an action strategy for the next ten years), and 2002 Madrid International Plan of Action on Ageing - a serious analysis of the problem of population Ageing worldwide, outlining the principles of the world community's work on it. Since then, the following changes took place:

- a number of international organizations deal with such issues: the International Federation of Associations for Elderly People (FIAPA); the International Federation of Ageing (IFA); the International Association of Gerontology and Geriatrics (IAGG); the International Network for the Prevention of Elder Abuse (INPEA), etc. However, these international organizations, firstly, are non-governmental, and second, aimed at certain social areas: culture, social support, leisure, etc.; 


\section{I}

GÊNERO E

INTERDISCIPLINARIDADE

- round tables and conferences are held (for example, the First World Assembly on Ageing in 1982, the International Conference on Ageing in 1992, and the Second World Assembly on Ageing in 2002), the International Year of Older Persons (IYOP) was proclaimed in 1999, and the International Day of Older Persons is observed on October 1 each year.

However, this is not enough:

1. Elderly persons have not yet been formally identified as a separate population group requiring special protection (although the necessity is widely recognized).

2. To recognize the above mentioned problem would mean to create an international intergovernmental organization with the appropriate powers (including those of imperious and administrative nature) to deal with complex issues of ensuring the rights of the elderly world population.

3. Considering the population is ageing worldwide, it is necessary to adopt appropriate universal international acts which contain provisions that could be applied to disclose the content of the legal status of elderly people at the national level. This would contribute to the uniformity of national legal regulation developed on the basis of
Vol $^{\circ} 02$ | nº 01 | ISSN: 2675-7451

https://www.periodicojs.com.br/index.php/gei/index

general international approaches, ideas and principles (Kurbatova, 2019a).

Thus, the authors of the present research consider it necessary to develop and adopt International Rules for the Participation of Seniors in Criminal Proceedings, which would enshrine the fundamental rights of older participants in criminal proceedings and guarantees for their implementation - by analogy with the Beijing Rules (United Nations, n.d.) containing the specifics of the implementation of criminal proceedings in relation to minors (Kurbatova, 2015).

However, such document should cover a wider range of criminal procedural relations and of types of participants than the current Beijing Rules. After all, the elderly (as well as minors) can participate in criminal proceedings not only as suspects, accused (defendants) but also be victims, witnesses, attesting witnesses, jurors, etc., which should also be taken into account in the legal settlement of their participant status. Accordingly, it would be more correct to have a wider coverage of possible options for juvenile participants in criminal proceedings.

Alternatively, the following structure of the International Rules for the Participation in Criminal 


\section{।}

GEENERO E

INTERDISCIPLINARIDADE

Proceedings of Seniors can be proposed:

1. Main objectives of the Rules;

2. Scope and basic concepts of the Rules;

3. Aims and objectives of criminal proceedings involving older persons;

4. Principles of criminal proceedings involving older persons;

5. Rights of older persons as participants in criminal proceedings;

6. Guarantees of participation in criminal proceedings for older persons:

a) initial contact;

b) obtaining evidence;

c) applying coercive measures;

d) participation of additional

subjects (lawyer, legal representatives, psychologist, etc.);

e) reports on the results of the social examination of the person;

f) Guidelines for adjudication and choice of remedies;

g) measures of influence;

h) providing the necessary assistance;

7. Specialization of the police, courts and other bodies;

8. Conciliation procedures;

9. Compensatory powers of the participating states in shaping the policy
Vol $^{\circ} 02$ | nº 01 | ISSN: 2675-7451

https://www.periodicojs.com.br/index.php/gei/index

of participation in criminal proceedings of older persons;

10. Final provisions.

The content of these points should:

- reflect the general goal of consolidating the compensatory norms, ensuring the possibility of equal participation in criminal proceedings for older persons;

- be based on the results of comprehensive scientific research;

- enable the participating states at their national level to expand the rights of older persons and introduce additional guarantees.

The main compensatory provisions to be reflected in the Rules will include the following:

1) For persons who have reached the age of 75 , participation of a legal representative, a lawyer (including at the expense of the state), a psychologist or an employee of social services (preferably specialists in the field of gerontology) is obligatory.

For persons aged 65-75, participation of these subjects is at the discretion of the person conducting the criminal case or on the basis of a reasoned application by the person from this age group or their relatives and other interested persons. 


\section{I}

GÊNERO E

INTERDISCIPLINARIDADE

It is necessary to define and study the circumstances that influence older persons on the level of their cognitive capabilities (Bertovskiy, 2019). When preparing for investigative and other procedural actions with the participation of older persons, one is to study their personality, determine the place, time and composition of the participants in the investigative action, to choose the tactics of its conduct, etc.

2) It is important to provide for less time-consuming investigative and other procedural actions with the participation of older persons. For instance, in Russia, interrogation of an adult cannot continue for more than 4 hours running, not more than 8 hours in total (Parts 2, 3 of Article 187 of the Criminal Procedure Code of the Russian Federation). Interrogation, confrontation, identification and verification of testimony with the participation of a minor under the age of seven cannot continue without a break for more than 30 minutes (more than 1 hour in total), aged seven to fourteen more than 1 hour (more than 2 hours in total), over the age of fourteen - more than 2 hours (more than 4 hours in total) a day. During these investigative actions, a legal representative of a minor victim or witness has the right to be present, and
$\mathrm{Vol}^{\circ} 02$ | nº 01 | ISSN: $2675-7451$

https://www.periodicojs.com.br/index.php/gei/index

if this is a minor accused, must be present (Articles 191, 425 of the Criminal Procedure Code of the Russian Federation). It would be logical to introduce such periods of duration in relation to older persons, for example, by highlighting the age groups: $75-80$ years, $80-85$ years, 85 years and older.

At the national level, when shaping criminal policy, more attention should be paid to issues of restorative justice (Zehr, 1990). In many European countries, it has been concretized in relation to minors (Shilovskaya, Sitdikova, 2018). The development of the institution of restorative justice has changed the approach and ways of responding to juvenile delinquency, both in the juvenile justice system itself and in the work of social sector services, while the justice itself has not changed. Nearly 40 European countries apply some form of restorative justice, and some of them (Austria, Belgium, Finland, Germany, the Netherlands and Northern Ireland) have specific national strategies in this area. For example, in Austria mediation of offender and victim (Tatausgleich) has been legislated since 1988 for minors, and for adults since 2000 (Gombots, Pelikan, 2015). In Greece, parents are present at the mediation procedure together with the victim and 


\section{1}

E GEnero e

INTERDISCIPLINARIDADE

the juvenile offender; there may also be other close persons on both sides (Artinopoulou, 2013). This kind of positive experience of progressive states can be used when introducing elements of restorative justice and with the participation of people of older age groups. In particular, it is possible to single out those types of crimes for which restorative justice in relation to older persons would be highly effective.

Other compensatory provisions may be proposed, some of them of universal international legal nature, mandatory for implementation in individual states or on the national level, taking into account the characteristics of these states and their capabilities.

\section{Conclusion}

The conducted research leads to the following conclusions:

- to ensure the uniformity of the formation and development of the legal status of the elderly as participants in different types of legal relations at the level of specific states, it is necessary to internationally recognize the elderly as an independent category of the population and to consolidate this in the norms of international legal acts of both general and special nature;
$\mathrm{Vol}^{\circ} 02$ | nº 01 | ISSN: $2675-7451$

https://www.periodicojs.com.br/index.php/gei/index

- the main general, universal act should be the Convention on the Rights of the Elderly, which would consolidate the main provisions of the age characteristics of older persons in the context of their legal status as participants in legal relations;

- there should also be special international acts which would develop and supplement the provisions of the Convention:

* firstly, those acts that already exist (acts of the International Labor Organization, the World Health Organization, etc.) should be brought in line with the provisions of the Convention on the Rights of the Elderly; * second, it is necessary to adopt new acts that consolidate the peculiarities of the participation of older persons in various spheres and sectors of life, in particular, in criminal proceedings (for example, the International Rules for the Participation of Older Persons in Criminal Proceedings);

- all this should be implemented at the level of specific states, detailed in their legislation taking into account the peculiarities of national legal systems;

an intergovernmental organization on the rights of the elderly at the UN level is needed to monitor the 


\section{I}

GÊNERO E

INTERDISCIPLINARIDADE

observance of all the above mentioned rules and to facilitate further implementation and protection of the rights of the elderly.

With regard to criminal proceedings, it must be stated that older persons are in an unequal position in relation to other participants. Due to agerelated changes, their cognitive functions become less active. As a result, such persons are no longer able to fully understand what is happening, to direct their actions, or to exercise their procedural rights, yet numerous international legal documents speak of equal rights of people. Therefore, to equalize the legal status of older persons, it is necessary to have compensatory legal norms. Accordingly, an international legal act is needed, which would:

- take into account the peculiarities of the legal personality of such participants in legal relations due to cognitive and (or) physical characteristics of older people due to the weakening of their body and of its functions;

- to endow elderly participants in legal relations with additional rights and guarantees for their implementation, taking into account the specifics of the scope of participation;
$\mathrm{Vol}^{\circ} 02$ | nº 01 | ISSN: $2675-7451$

https://www.periodicojs.com.br/index.php/gei/index

- to impose on states specific obligations to ensure the conditions for the realization of these rights, by analogy with the Beijing UN rules of 1985 , containing the specifics of the implementation of criminal proceedings in relation to minors. For instance, the structure and some postulates of the International Rules for the Participation in Criminal Proceedings of Older Persons are proposed in the present research.

\section{Acknowledgements}

The paper was written and published under the grant of the Russian Foundation for Basic Research 'Scientific and expert study of Russia's criminal policy in the modern multipolar world' (grant competition of the Corporate Information and Analytical System of the Russian Foundation for Basic Research, application No. 20-01100536).

\section{References}

Age dependency ratio, old (\% of working-age population) - Russian Federation, United Kingdom, Japan, Brazil, Korea, Rep. URL: https://data.worldbank.org/indicator/SP. POP.DPND.OL?locations=RU-GB-JPBR-KR Agnew, R., DeLisi, M., 2012. 


\section{I}

GÊNERO E

INTERDISCIPLINARIDADE

General strain theory, the criminal justice system and beyond: introduction to the special issue. Journal of Criminal Justice 40 (3), 174-175

Aguzumtsyan, R.V., Muradyan, E.B., 2008. Psychological safety of the individual in the periods of late adulthood and old age. Psychological Journal 29 (3), 22-29.

Artinopoulou, V., 2013. Restorative justice in criminal matters: towards a new European Perspective. AthensThessaloniki: Sakkoulas Publications.

Bertovskiy, L.V., 2019. On obtaining verbal information from persons with cognitive disabilities. Modern youth and the challenges of extremism and terrorism in Russia and abroad. Collection of materials of the AllRussian (with international participation) scientific-practical conference. Gorno-Altaysk: Gorno-Altai State University.

Blekharskaya, E.V., 2017. Elderly age as a transitional stage in a person's life path. Pedagogical Education in Russia 12, 3643.

Cavallini, E., Lecce, S., 2013. Beyond false belief: theory of mind in young, young-old, and old-old adults. Int $\mathrm{J}$ Ageing Hum Dev 76 (3),181-198.

Choong, C., Doody, G., 2013. Can theory of mind deficits be measured
$\mathrm{Vol}^{\circ} 02$ | nº 01 | ISSN: $2675-7451$

https://www.periodicojs.com.br/index.php/gei/index

reliably in people with mild and moderate Alzheimer's dementia? BMC Psychology 28 (1), 1-9.

Credit Suisse, Russian. URL: https://www.creditsuisse.com/ru/ru.html

Credit Suisse, English. URL: https://www.creditsuisse.com/ch/en.html

Federal State Statistics Service. URL: https://rosstat.gov.ru/

Galperin, I.M., Kurlyandsky, V.I., 1975. The subject of criminal policy and the main directions of its study. The main directions of the fight against crime. Moscow: Yurist.

Gombots, R., Pelikan, C., 2015. Restorative justice and mediation in penal matters - a stocktaking of legal issues, implementation strategies and outcomes in 36 European countries. Mönchengladbach: Verlag Godesberg. Goryunova, N.B., Voronin, A.N., 2016. Cognitive resource. Structure, dynamics, development. Moscow: Institute of Psychology of RAS.

Grinenko, A.V., Gudzhabidze, G.A., Potapov, V.D., Zheleznyak, N.S., 2020. Categories of rights and legitimate interests of the individual and their use in the criminal sphere. All-Russian criminological journal 14 (1), 139-147. 


\section{1}

GÊNERO E

INTERDISCIPLINARIDADE

Kesaeva, M.S., 2017. Problems of harmonizing criminal procedural guarantees of individual rights and differentiating between forms of pre-trial proceedings in criminal cases. $\mathrm{PhD}$ thesis. N. Novgorod: NSU.

Kurbatova, S.M., 2015. International legal regulation as a guarantee of the implementation of the legal status of underage suspects accused in criminal proceedings. Kazan Science 5, 125-127. Kurbatova, S.M., 2019a. Formation of a cognitive approach to understanding a person with disabilities at the international legal level and its impact on national law (on the example of Russian criminal procedure legislation). Questions of Russian and International Law 9 (8-1), 134-143.

Kurbatova, S.M., 2019b. On understanding the social state as a means of ensuring the implementation of the legal status of persons with limited cognitive abilities (on the example of criminal procedural law). Law and Politics 8, 119-129.

Morris, R. G. et al., 2012. Does prison strain lead to prison misbehavior? An application of general strain theory to inmate misconduct. Journal of Criminal Justice 40 (3), 194-201.

Malysheva, O.A., 2005. Criminal procedure policy as an element of unified
$\mathrm{Vol}^{\circ} 02$ | nº 01 | ISSN: 2675-7451

https://www.periodicojs.com.br/index.php/gei/index

criminal policy. Russian Investigator 8, 19-21.

Melekhin, A.I., Sergienko, E.A., 2015. Specificity of social cognition in the old and senile age. Social Psychology and Society 6 (4), 60-77.

Musiychuk, M.V., Shuleva, E.I., 2018. Dynamics of mental states of persons under investigation. All-Russian Criminological Journal 12 (6), 874-884. Raz, N., 2000. Ageing of the brain and its impact on cognitive performance: integration of structural and functional findings. In: Craik, F.I.M. and Salthouse, T.A., eds. The handbook of ageing and cognition. Mahwah: Lawrence Erlbaum Associates Publishers.

Rwei-Ling, Y, Ruey-Meei, W., 2013. Social brain dysfunctions in patients with Parkinson's disease: a review of theory of mind studies. Translational Neurodegeneration 7, 1-6.

Shilovskaya, A.L., Sitdikova, L.B., 2018. The use of restorative justice for minors in Europe. All-Russian Criminological Journal 12 (1), 141-151. Sorokina, E.M., 2016. Harmonization of criminal procedure law in the European Union. PhD thesis. Moscow: MSJA.

United Nations.

URL: https://www.un.org/

Wang, Z., Su, Y., 2013. Age-related differences in the performance of theory 
of mind in older adults: a dissociation of

cognitive and affective components. Psychological Ageing 1, 284-291.

Yakimovich, N.V. Brain nutrition and age-related decline in intelligence. URL: http://www.ortho.ru/5_Guest/mozg2_0. $\underline{\mathrm{htm}}$

Larry, R., 1987. Squire memory and brain. Oxford: OUP.

Zehr, H., 1990. Changing lenses. a new focus for crime and justice. NY: Herald Press.

Zerbi, Valerio, Floriou-Servou, Amalia, Markicevic, Marija,..., De Deyn, Peter Paul, Wenderoth, Nicole, Bohacek, Johannes. Rapid Reconfiguration of the Functional Connectome after Chemogenetic Locus Coeruleus Activation 